J. Agrifarm : Vol. 8 No. 1, Juli 2019 P- ISSN : 2301-9700, E- ISSN : 2540-8892

\title{
Pemanfaatan Limbah Cair Pabrik Kelapa Sawit Sebagai Bioaktivator Untuk Pengomposan Tandan Kosong Kelapa Sawit
}

\author{
Utilization of Palm Oil Mill Liquid Waste as Bioactivator for Composting Oil Palm Empty Fruit Bunches
}

\section{Zainudin, Abdul Rofik}

Tenaga Pendidik Program Studi Agroteknologi, Fakultas Pertanian, Universitas Widya Gama Mahakam

Jl. KH. Wahid Hasyim, Sempaja, Samarinda, Kalimantan Timur, Indonesia

Email : ztjimpolo@gmail.com, birudaun83@gmail.com

Diterima : 4 April 2019 Disetujui : 17 Juni 2019

\begin{abstract}
Palm oil is an export commodity of the plantation sector which began to develop rapidly in East Kalimantan with an area until 2017 reaching 1,192,342 Ha consisting of 284,523 Ha as plasma / smallholder plants, 14,402 Ha owned by SOEs as the core and 893,417 Ha owned by Large Private Plantation.

Empty bunches (Tankos) are solid waste that is produced by palm oil mills in the process of managing palm fruit bunches into crude palm oil (CPO). In each processing 1 ton of fruit bunches will produce Tankos as much as 21-23\%. Oil palm empty fruit bunches that are not managed properly will become waste that does not provide benefits. Compost technology using a local microorganism starter (MOL) can be used to produce quality organic fertilizer considering the process involves decomposing bacteria of organic ingredients. Compost technology from tankos waste is very possible to be developed, both at the level of farmers and private oil palm companies. This study aim to determine the potential of palm oil mill effluent (POME) as an bioactivator for composting oil palm empty fruit bunches, and to determine the chemical quality of oil palm empty fruit bunch compost with MOL bioactivator liquid waste as organic fertilizer. Through this research, it is expected that the palm oil mill's liquid waste can be utilized as a bioactivator for compost production and can be applied to the production of oil palm empty fruit bunch compost.

This research was conducted for one year. The stages of the research are as follows: 1 . Chemical analysis of POME waste, 2. Making LM POME, 3. Chemical analysis of LM POME, and 4. Making EFB Compost, and Chemical Analysis of oil palm empty fruit bunch compost. Compost making using randomized block design (RBD) with 5 treatments and 4 replications include: $P O=0 \mathrm{ml} /$ liter of water, $P 1=100 \mathrm{ml} /$ liter of water, $P 2=300 \mathrm{ml} /$ liter of water, $P 3=600 \mathrm{ml} /$ liter of water, $P 4=900 \mathrm{ml} /$ liter of water.

The analysis showed that there was an increase in the chemical properties of POME after becoming an LM POME activator. Increased chemical properties such as phosphorus from 0.01 to 0.02 , potassium from 0.19 to 0.27 , and organic carbon from 0.90 to 1.30, but some chemical properties such as $\mathrm{pH}$ decreased from 7.20 to 3, 37 and nitrogen decreased from 0.37 to 0.05. The EFB compost analysis results showed that the highest $p H$ was $p 2$ with a value of 8.23 , the highest organic $C$ at $p 4$ treatment with a value of 57.65 , the highest total $\mathrm{N}$ at $\mathrm{p} 3$ with a value of $1.80, \mathrm{P}_{2} \mathrm{O}_{5}$ the highest total at $\mathrm{p} 3$ with a value of 0.64 , and the highest total $\mathrm{K}_{2} \mathrm{O}$ at $\mathrm{p} 4$ with a value of 2.68 .
\end{abstract}

Keywords : Liquid waste, bioactivator, oil palm

\section{PENDAHULUAN}

Pertanian organik merupakan sistem pertanian yang sedang gencar dikembangkan termasuk di Kalimantan Timur (Kaltim). Sistem pertanian organik sangat penting terutama untuk memperbaiki kondisi tanah di Kaltim yang sebagian besar berupa tanah bekas penambangan batubara. Tanah bekas penambangan batubara apabila ingin dikembangkan sebagai areal pertanian maka perlu pengelolaan yang berkelanjutan berupa penggunaan pupuk organik secara terus menerus agar kondisi tanah dapat sesuai untuk budidaya pertanian.

Faktor penting dalam sistem pertanian organik yang dikembangkan adalah pupuk organik. Pupuk organik berasal dari bahan organik sebaiknya melalui proses pengomposan agar lebih cepat 
menyediakan unsur hara bagi tanaman. Proses pengomposan memerlukan bioaktivator untuk mempercepat terjadinya dekomposisi bahan organik. Pemilihan bioaktivator yang digunakan dalam proses pengomposan harus cermat mengingat setiap bahan organik memiliki $\mathrm{C} / \mathrm{N}$ rasio yang berbeda.

Mikroorganisme lokal (MOL) merupakan salah satu dekomposer yang dapat digunakan dalam pembuatan kompos. Penggunaan bioaktivator dengan memanfaatkan jenis MOL menjadi alternatif penunjang kebutuhan unsur hara untuk pengomposan bahan organik.

Pesatnya perkembangan industri kelapa sawit diiringi dengan perkembangan limbah cair dan padat yang cukup besar misalnya limbah tandan kosong kelapa sawit. Material kompos yang digunakan pada penelitian ini adalah tandan kosong kelapa sawit yang menjadi limbah pabrikpabrik kelapa sawit di wilayah kabupaten/kota seprovinsi Kalimantan Timur. Pada tahun 2012 produksi Tandan Buah Segar TB kelapa sawit di Kalimantan Timur sebesar 775 ton per hari. Jika diolah menjadi CPO akan menghasilkan limbah cangkang 5 persen, serabut 12 persen, dan tandan kosong 23 persen. Pemanfaatan kompos tandan kosong kelapa sawit masih jarang terutama di kalangan petani di Kaltim. Padahal teknologi produksi kompos dari tandan kosong sawit (TKS) merupakan satu teknologi pengolahan limbah yang sekaligus dapat mengatasi masalah limbah padat dan limbah cair di pabrik pengolahan kelapa awit hingga pabrik mempu menerapkan konsep zero waste yang berarti tidak ada lagi limbah padat dan cair yang terbuang.

Teknologi kompos dengan menggunakan starter mikroorganisme lokal (MOL) limbah cair pabrik kelapa sawit diyakini dapat digunakan untuk menghasilkan pupuk organik berkualitas mengingat pada prosesnya melibatkan bakteri pengurai bahan organik. Teknologi kompos asal limbah tandan kosong kelapa sawit sangat memungkinkan untuk dikembangkan, baik di tingkat petani maupun perusahan swasta kelapa sawit.

\section{BAHAN DAN METODE}

Penelitian dilakukan selama kurang lebih 1 (satu) tahun, mulai Bulan April 2018 hingga Nopember 2018. Penelitian ini dilakukan di Fakultas Pertanian Universitas Widyagama Mahakam Samarinda, Kalimantan Timur. Analisis larutan mikroorganisme (MOL) dan kompos di lakukan di laboratorium Tanah Fakultas Pertanian Universitas Mulawarman.
Penelitian dilakukan dengan pembuatan larutan MOL, pembuatan kompos tandan kosong kelapa sawit, pembuatan kompos limbah tandan kosong kelapa sawit menggunakan rancangan dengan 5 perlakuan dan 4 ulangan, yaitu ; $\mathrm{P} 0=0 \mathrm{ml}$ MOL/liter air, P1 = $100 \mathrm{ml} \mathrm{MOL/liter} \mathrm{air,} \mathrm{P2} \mathrm{=}$ $300 \mathrm{ml} \mathrm{MOL} /$ liter air, P3 $=600 \mathrm{ml} \mathrm{MOL} /$ liter air dan P4 $=900 \mathrm{ml} \mathrm{MOL/liter} \mathrm{air.} \mathrm{Penelitian} \mathrm{ini}$ melakukan beberapa analisis yaitu ; analisis limbah cair, analisis MOL limbah cair dan analisis kompos tandan kosong kelapa sawit dengan parameter : reaksi tanah $(\mathrm{pH})$ ditetapkan dengan metode ekstraksi dengan perbandingan 1:2,5 dan diukur dengan alat $\mathrm{pH}$ meter elektroda, C-Organik ditetapkan berdasarkan metode Walkley dan Black, di ukur dengan menggunakan Spektrofotometer, bahan organik ditetapkan dengan perhitungan :

$$
\text { Bahan Organik }=\% \text { C x 1,724 }
$$

a. Unsur Nitrogen total ditetapkan berdasarkan metode destilasi Kjeldah, dengan titrasi tahap akhir menggunakan 0,02 N HCL.

b. Unsur P dan K tersedia ditetapkan berdasarkan metode Morgan.

c. $\mathrm{C} / \mathrm{N}$ ratio dihitung dengan menggunakan rumus :

$$
\mathrm{c} / \mathrm{N}=\frac{\% \mathrm{C}}{\% \mathrm{~N}}
$$

Analisis data tanah dilakukan dengan kriteria penilaian sifat kimia tanah berdasarkan BPT Bogor (2009). Analisis data kompos menggunakan standar mutu pupuk organik 70/Permentan/Sr.140/10/2011: 25 Oktober 2011

\section{HASIL DAN PEMBAHASAN}

\section{Hasil Analisis Larutan Mikro Organisme (MOL) POME}

POME segar memiliki panas $\left(80-90^{\circ} \mathrm{C}\right)$, memiliki $\mathrm{pH}$ masam ( $\mathrm{pH} 4-5)$ dengan bau yang tidak menyenangkan, dan suspensi koloid tinggi; yang terdiri dari terutama air, minyak dan total padatan termasuk padatan tersuspensi dari serpihan buah sawit. POME adalah hasil dari pengolahan TBS terutama dari proses fisik seperti sterilisasi, proses klarifikasi dan pemisahan minyak sawit. Beberapa peneliti menyatakan bahwa warna gelap dan kecoklatan POME dapat dikaitkan dengan perincian lignoselulosa dari efluen mentah menjadi lignin dan tannin. POME juga mengandung berbagai jenis senyawa organik 
yang terutama diekstrak pigmen dari sterilisasi TBS, seperti anthocyanin dan pigmen karoten. (S. P. D. Kaman, I.A.W. Tan and L. L. P. Lim. 2017).

POME dapat dimanfaatkan untuk kegiatan pertanian di mana dapat diubah menjadi bahan yang bermanfaat melalui proses mikroba. POME mengandung konsentrasi protein tinggi, senyawa nitrogen, karbohidrat, lipid dan mineral yang berfungsi sebagai sumber makanan untuk mikroorganisme. Perubahan POME dapat melalui proses anaerobik di mana mikroorganisme memecah bahan biodegradable dengan tidak adanya oksigen. (S. Adam, S.S.N. Syd Ahmad, N.M. Hamzah, N.A. Darus, N.M. Hamzah, N.A. Darus, 2016)

\section{Reaksi Tanah (pH)}

Karakteristik Palm Oil Mill Effluent (POME) atau limbah cair pabrik kelapa sawit tergantung pada kualitas bahan baku dan proses produksi minyak sawit di pabrik kelapa sawit.

Proses fermentasi anaerob akan menghasilkan beberapa zat, seperti etanol dan gas metana yang bisa sumber energi alternatif. Etanol dapat diproduksi melalui jalur dalam proses fermentasi yang melibatkan di setidaknya tahapan berikut: hidrolisis, fermentasi, distilasi, dan dehidrasi. Pembentukan etanol di bawah kondisi anaerobik disebabkan oleh adanya dekarboksilase piruvat dan alkohol dehidrogenase enzim dalam fase asidogenesis. Sebagai proses biologis, fermentasi sangat bergantung pada beberapa faktor, termasuk $\mathrm{pH}$, oksigen dan suhu, yang dapat sangat mempengaruhi laju pertumbuhan spesifik, dan kehadiran enzim modulator. (Tia W. P., and M. Syafila. 2018).

Proses fermentasi limbah cair pabrik kelapa sawit menjadi larutan mol POME mengakibatkan perubahan $\mathrm{pH}$ larutan yang ditunjukkan oleh tabel 1. Berdasarkan hasil analisis, larutan mol mengalami penurunan $\mathrm{pH}$ dari awalnya limbah pome memiliki pH 7,20 setelah mengalami fermentasi menjadi mol $\mathrm{pH}$ mengalami penurunan menjadi 3,37. Air limbah termasuk konstituen terlarut dengan konsentrasi tinggi protein, karbohidrat, senyawa nitrogen, lipid dan mineral, yang dapat diubah menjadi bahan yang bermanfaat menggunakan proses mikroba. Limbah dari pabrik kelapa sawit dapat menyebabkan masalah lingkungan yang cukup besar, jika dibuang tanpa perawatan.

Pembuatan larutan mikroorganisme (MOL) merupakan proses fermentasi yang akan menghasilkan gas seperti $\mathrm{CO}_{2}$. Terlepasnya $\mathrm{CO}_{2}$ dalam larutan akan membentuk senyawa asam karbonat $(\mathrm{H})$ yang mudah terurai menjadi ion-ion $\mathrm{H}^{+}$dan $\mathrm{HCO}_{3}^{-}$. Ion-ion $\mathrm{H}^{+}$ini akan menentukan kemasaman. Makin lama waktu fermentasi berlangsung, maka tingkat dekomposisi bahan organik akan semakin lanjut. Kondisi ini mengakibatkan peningkatan konsentrasi ion-ion $\mathrm{H}^{+}$dalam larutan fermentasi sehingga $\mathrm{pH}$ menjadi lebih rendah. Penurunan $\mathrm{pH}$ mengakibatkan jumlah muatan positif meningkat dan menyebabkan muatan permukaan partikel lumpur hampir netral. Penurunan $\mathrm{pH}$, telah menyebabkan penurunan dalam aktivitas metanogenik dan biomassa.

Tabel 1. Hasil analisis pH limbah POME dan Mol POME

\begin{tabular}{|c|c|c|}
\hline No & Larutan & $\mathrm{pH}$ \\
\hline 1 & Limbah POME & 7,20 \\
\hline 2 & Mol POME & 3,37 \\
\hline
\end{tabular}

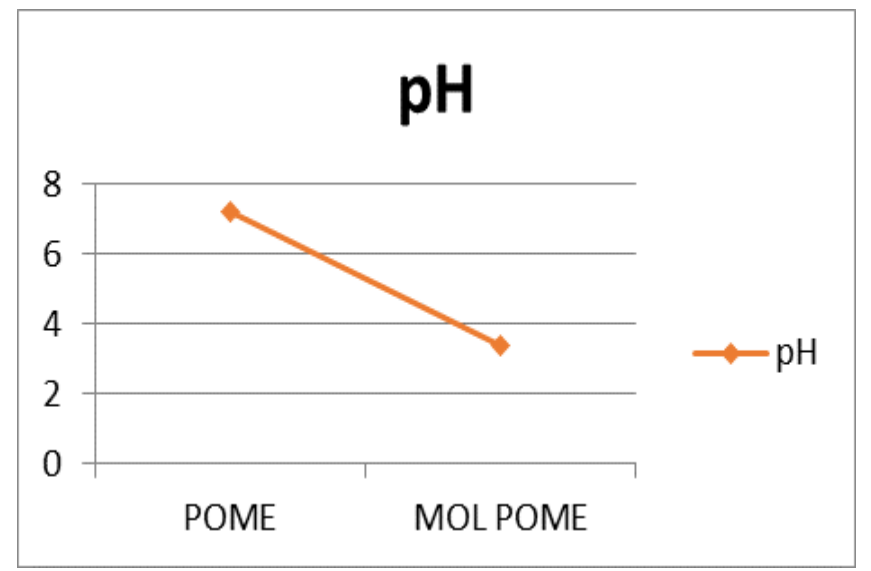

Grafik 1. Perubahan $\mathrm{pH}$ limbah POME setelah proses fermentasi larutan Mol 


\section{Nitrogen}

Proses fermentasi larutan mol POME mengakibatkan perubahan kandungan unsur hara dalam hal ini adalah kandungan Nitrogen (\%) yang ditunjukkan oleh tabel 2 .

Proses fermentasi yang terjadi pada larutan mol POME mengakibatkan unsur nitrogen mengalami penurunan dari $0,37 \%$ pada limbah cair POME menjadi 0,05\% pada larutan Mol POME. Ditambahkan oleh Buckle et al.(1987) dalam Supriyati, T, dkk (1998) menyatakan bahwa untuk hidup semua organisme membutuhkan sumber energi yang diperoleh dari metabolisme bahan pangan tempat organisme berada di dalamnya, dalam hal ini adalah larutan mol POME.

Penurunan kandungan Nitrogen disebabkan karena nitrogen dalam bentuk amonia sebagai hasil dari dekomposisi bahan organik sebagian besar hilang ke udara. Fermentasi pada larutan mikroorganisme mol POME memanfaatkan mikroorganisme yang bersumber dari bahan asal berupa limbah cair POME yang akan menguraikan bahan organik yang ada di dalam larutan POME. Selama proses fermentasi masih berlangsung maka Nitrogen akan dimanfaatkan oleh mikroorganisme sehingga dalam pembuatan larutan mol akan terjadi penurunan kandungan nitrogen.

Tabel 2. Hasil analisis Nitrogen limbah POME dan Mol POME

\begin{tabular}{|c|c|c|}
\hline No & Larutan & Nitrogen $(\%)$ \\
\hline 1 & Limbah POME & 0,37 \\
\hline 2 & Mol POME & 0,05 \\
\hline
\end{tabular}

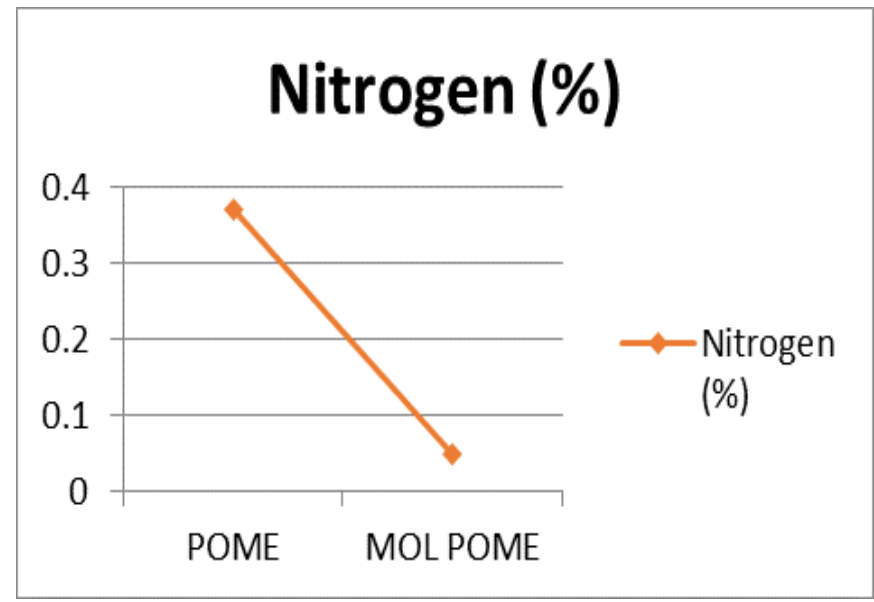

Grafik 2. Perubahan Nitrogen limbah POME setelah proses fermentasi larutan Mol

\section{Fosfor}

Proses fermentasi larutan mol POME mengakibatkan perubahan kandungan unsur hara dalam hal ini adalah kandungan $\mathrm{P}_{2} \mathrm{O}_{5}$ total (\%) yang ditunjukkan oleh tabel 3. Berdasarkan hasil analisis laboratorium, unsur Fosfor mengalami peningkatan dari limbah pome $\mathrm{P}_{2} \mathrm{O}_{5}$ total sebesar $0,01 \%$ meningkat menjadi $0,02 \%$ setelah larutan pome dibuat menjadi mol.

Tabel 3. Hasil analisis Fosfor limbah POME dan Mol POME

\begin{tabular}{|c|c|c|}
\hline No & Larutan & $\mathrm{P}_{2} \mathrm{O}_{5}$ total $(\%)$ \\
\hline 1 & Limbah POME & 0,01 \\
\hline 2 & Mol POME & 0,02 \\
\hline
\end{tabular}




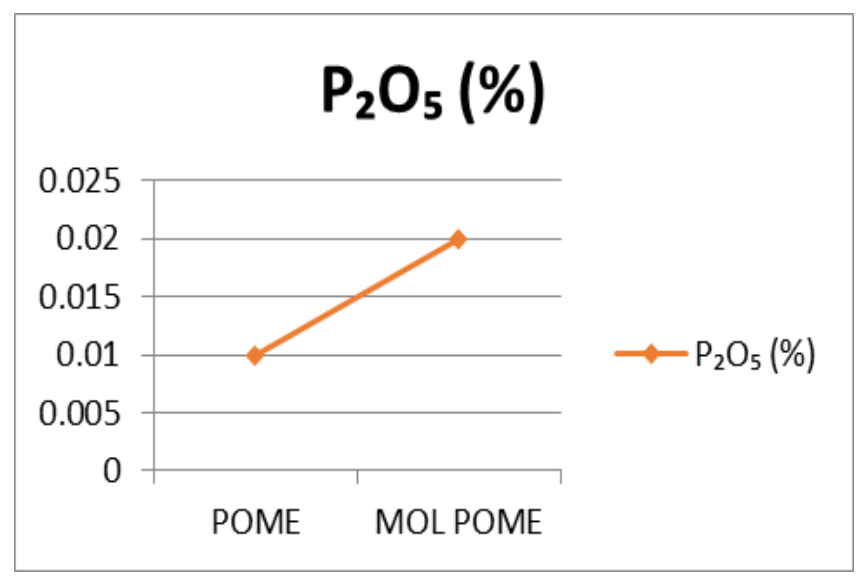

Grafik 3. Perubahan Fosfor limbah POME setelah proses fermentasi larutan Mol

\section{Kalium}

Proses fermentasi larutan mol POME mengakibatkan perubahan kandungan unsur hara dalam hal ini adalah kandungan $\mathrm{K}_{2} \mathrm{O}$ total (\%) yang ditunjukkan oleh tabel 4. Berdasarkan hasil analisis laboratorium, unsur kalium mengalami peningkatan dari limbah pome $\mathrm{K}_{2} \mathrm{O}$ total sebesar $0,19 \%$ meningkat menjadi 0,27 $\%$ setelah larutan pome dibuat menjadi mol.

Dalam pembuatan mol aktivitas mikroba memiliki peranan penting. Mikroba berfungsi untuk merombak bahan organik (dekomposer), nitrifikasi, denitrifikasi, pelarut fosfat, dan lain-lain. Mikroorganisme perombak bahan organik dalam larutan mol berasal dari bahan organik yang ditambahkan. Keefektifan mikroorganisme dalam mempercepat proses dekomposisi dan melepaskan unsur hara tergantung pada jumlah dan jenis mikroorganime. Di dalam larutan mol, mikroorganisme perombak bahan organik memegang peranan penting karena sisa organisme yang telah mati akan diurai menjadi unsur-unsur yang dikembalikan ke dalam tanah dalam bentuk hara mineral $\mathrm{N}, \mathrm{P}, \mathrm{K}, \mathrm{Ca}, \mathrm{Mg}$, dan atau dalam bentuk gas yang dilepas ke atmosfer berupa $\mathrm{CH}$ atau $\mathrm{CO}$.

Tabel 4. Hasil analisis Kalium limbah POME dan Mol POME

\begin{tabular}{|c|c|c|}
\hline No & Larutan & $\mathrm{K}_{2} \mathrm{O}$ total (\%) \\
\hline 1 & Limbah POME & 0,19 \\
\hline 2 & Mol POME & 0,27 \\
\hline
\end{tabular}

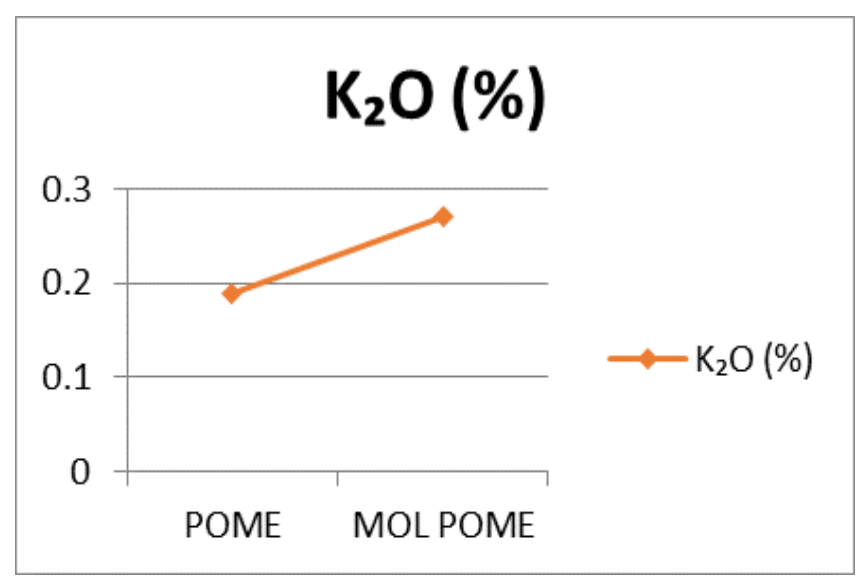

Grafik 4. Perubahan Kalium limbah POME setelah proses fermentasi larutan Mol

\section{Karbon}

Proses fermentasi larutan mol POME mengakibatkan perubahan kandungan unsur hara dalam hal ini adalah kandungan karbon organik yang ditunjukkan oleh tabel 5 .

Berdasarkan hasil analisis laboratorium diperoleh bahwa terjadi peningkatan kandungan 
C organik setelah proses pembuatan larutan mol, hal ini disebabkan karena penambahan bahan tambahan dalam pembuatan mol yaitu air cucian beras yang merupakan sumber karbohidrat

Tabel 5. Hasil analisis Karbon organik limbah POME dan Mol POME

\begin{tabular}{|c|c|c|}
\hline No & Larutan & C organik (\%) \\
\hline 1 & Limbah POME & 0,90 \\
\hline 2 & Mol POME & 1,30 \\
\hline
\end{tabular}

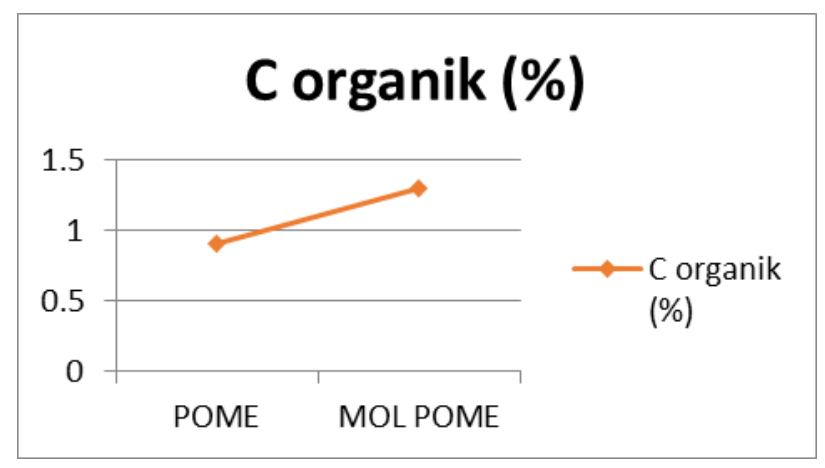

Grafik 5. Perubahan karbon organik limbah POME setelah proses fermentasi larutan Mol

Menurut Parveen F. R., Rajeev P. S., M. Hakimi, I., And Norizan, E. (2010) bahwa POME dianggap tidak beracun, tetapi merupakan sumber utama polusi air dengan kadar BOD yang tinggi. POME mengandung sejumlah besar $\mathrm{N}, \mathrm{P}, \mathrm{K}, \mathrm{Mg}$

\section{Hasil Analisis Kompos}

Penerapan POME dalam proses dekomposisi kompos bisa mempercepat dekomposisi bahan kompos karena kadar air yang tinggi. Kandungan dan $\mathrm{Ca}$, yang merupakan elemen nutrisi penting untuk pertumbuhan tanaman, karena sifatnya yang tidak beracun, POME dapat digunakan sebagai pupuk atau pakan ternak pengganti untuk menyediakan mineral yang cukup.

kelembaban telah digambarkan sebagai faktor penting yang memastikan dan mempercepat dekomposisi bahan kompos (Chang dan Chen 2010).

Tabel 6. Hasil analisis kompos tandan kosong kelapa sawit dengan aktivator mol POME

\begin{tabular}{|c|c|c|c|c|c|c|c|}
\hline No & Perlakuan & $\mathrm{pH}$ & $\mathrm{C}$ org $(\%)$ & $\mathrm{N}(\%)$ & $\mathrm{C} / \mathrm{N}$ rasio & $\begin{array}{c}\mathrm{P}_{2} \mathrm{O}_{5} \text { total } \\
(\%)\end{array}$ & $\begin{array}{c}\mathrm{K}_{2} \mathrm{O} \text { total } \\
(\%)\end{array}$ \\
\hline 1 & $\mathrm{P} 0$ & 8,10 & 50,23 & 1,76 & 28 & 0,46 & 2,14 \\
\hline 2 & $\mathrm{P} 1$ & 8,12 & 48,13 & 1,23 & 39 & 0,29 & 2,23 \\
\hline 3 & $\mathrm{P} 2$ & 8,23 & 51,40 & 1,51 & 34 & 0,45 & 2,33 \\
\hline 4 & $\mathrm{P} 3$ & 8,19 & 43,63 & 1,80 & 24 & 0,64 & 2,66 \\
\hline 5 & $\mathrm{P} 4$ & 8,15 & 57,65 & 1,26 & 45 & 0,30 & 2,68 \\
\hline
\end{tabular}

Sumber : Analisis data primer di laboratorium Ilmu Tanah Faperta Unmul

Berdasarkan standar mutu pupuk organik padat Nomor Tanggal: 70/Permentan/Sr.140/10/2011: 25 Oktober 2011 nilai karbon organik kompos tandan kosong kelapa sawit telah memenuhi standar yaitu pada setiap perlakuan kadar $\mathrm{C}$ organik $>15 \%$. Berdasarkan rasio $\mathrm{C} / \mathrm{N}$ kompos tandan kosong kelapa sawit belum memenuhi standar mutu pupuk organik. Rasio $\mathrm{C} / \mathrm{N}$ berdasarkan standar mutu adalah 15-25. Nilai $\mathrm{pH}$ kompos tandan kosong kelapa sawit pada semua perlakuan telah memenuhi standar mutu pupuk organik padat.

Menurut ( S. Adam, S.S.N. Syd Ahmad, N.M. Hamzah, N.A. Darus, N.M. Hamzah, N.A. Darus, 2016) pH kompos yang berfluktuasi antara rentang 7.8-9.0 dalam waktu 10 minggu setelah proses pengomposan. Seperti yang disebutkan oleh Jusoh et al. (2013), kondisi alkalin 
menunjukkan kompos berkualitas baik dan dalam kisaran yang disarankan 6,0-8,5. Namun sebagaimana dinyatakan oleh Miller et al. (1991), $\mathrm{pH}$ kompos yang tinggi bisa menyebabkan hilangnya nitrogen sebagai $\mathrm{NH}_{3}$ dan menyebabkan masalah bau. Menurut Satisha dan
Devarajan (2007), peningkatan nilai pH dalam proses pengomposan kemungkinan terjadi akibat dari proses degradasi metabolik cepat dari asam organik dan proteolisis intens dari senyawa alkalin amonia.
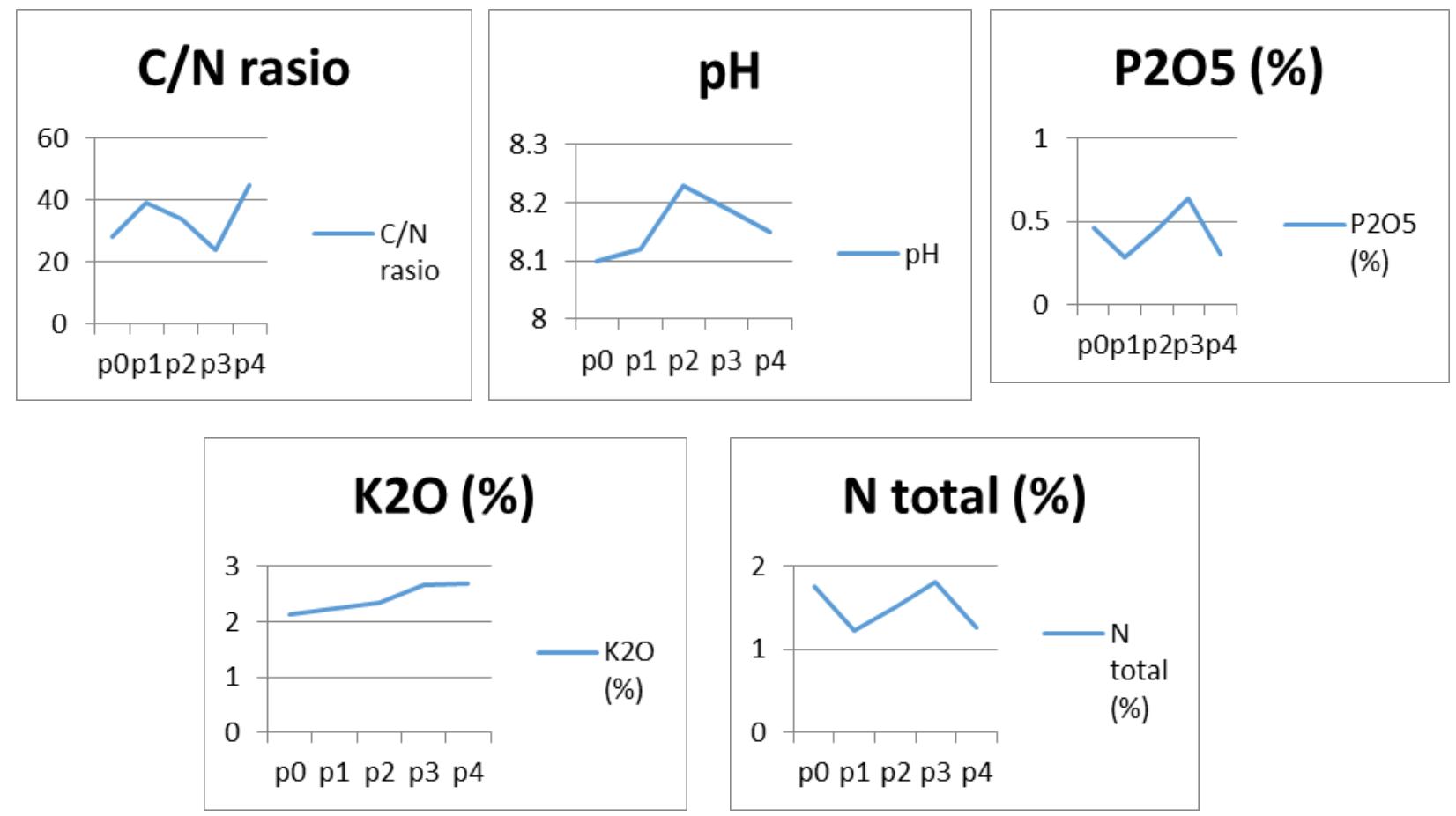

Grafik 6. Hasil analisis unsur hara kompos tandan kosong kelapa sawit dengan aktivator mol limbah cair

Berdasarkan kandungan unsur hara makro yang terdiri dari Nitrogen, Fosfor, dan kalium dengan kadar $\mathrm{N}+\mathrm{P}_{2} \mathrm{O}_{5}+\mathrm{K}_{2} \mathrm{O}$ minimal 4 , pada $\mathrm{p} 0$ kadar unsur hara makro memenuhi standar, pada perlakuan $\mathrm{p} 1$ unsur hara makro belum memenuhi standar, pada perlakuan $\mathrm{p} 2, \mathrm{p} 3$, dan $\mathrm{p} 4$ unsur hara makro memenuhi standar mutu pupuk organik padat dengan kadar unsur hara makro $>4$. Ditambahkan oleh Yahya dkk. (2010) menyelidiki pengomposan tandan kosong kelapa sawit dan decanter cake (DC) dengan menambahkan POME menghasilkan peningkatan proses pengomposan. Periode pengomposan selama 51 hari menghasilkan kompos yang telah matang dan mengandung $46,4 \%$ nitrogen, $17,9 \%$ fosfor, $17,7 \%$ potasium, dan 23,1\% kalsium.

Penambahan kompos dapat meningkatkan sifat kimia tanah dan mengurangi keasaman tanah. Penambahan kompos yang kaya akan $\mathrm{C}$ organik dapat mempengaruhi nilai $\mathrm{pH}$ dari media pertumbuhan. Selain itu, kandungan unsur alkali yang tinggi (Kation berlebih), Ca dan $\mathrm{Mg}$, seiring dengan peningkatan kompos yang dapat bereaksi dengan $\mathrm{H}^{+}$.
Degradasi karbon mencerminkan proses mineralisasi yang membuat semua nutrisi tersedia dalam bahan kompos, selain itu peningkatan $\mathrm{N}$ pada akhir proses pengomposan disebabkan karena aktivitas bakteri pengikat nitrogen umumnya terjadi pada akhir pengomposan (Jusoh et al. 2013). Menurut Budianta et al., konsentrasi $\mathrm{P}$ tersedia meningkat menjadi $73,82 \%$ saat kompos yang berasal dari limbah kelapa sawit diaplikasikan pada tanah, sementara Aluminium tertukar menurun, hal ini disebabkan oleh kehadiran kelompok fungsional permukaan negatif (fenolik, karboksilat, karbonil, dan alkohol) pada immobilisasi kompos $\mathrm{Al}$ atau $\mathrm{Fe}$ dan melepaskan P kembali ke tanah. Penambahan kompos juga mempengaruhi ketersediaan nutrisi dan retensi pada media tanam. Permukaan bahan organik seperti kompos kaya akan fungsi negatif seperti fenolik, karboksilat, karbonil, dan alkohol yang berfungsi sebagai situs pertukaran yang pada akhirnya meningkatkan KTK media pertumbuhan. Selanjutnya, akan meningkatkan produksi bahan kering dan memungkinkan penggunaan nutrisi yang efisien. (Rosenani., R. Rovica., P. M. Cheah., And C. T. Lim. 2016). 
Bernal, M. P., C. Paredes, M. A. Sanchez and J. Cegarra (1998) mengindikasikan bahwa nitrogen biasanya meningkat selama proses pengomposan. Peningkatan konsentrasi nutrisi ini mungkin terjadi karena mineralisasi limbah organik, disertai dengan pengurangan total volume limbah dalam kondisi ideal. Temuan ini di konfirmasi dengan temuan Metting, F. B (1993) yang melaporkan bahwa selama penguraian, mikroorganisme berasimilasi kompleks zat organik dan melepaskan nutrisi anorganik. Kavitha, B., P. Jothimani And G. Rajannan. (2013) menjelaskan bahwa penggunaan organisme kombinasi Streptomyces sp., Bacillus sp. dan P. Chrysosporium pada pengomposan kompos tandan kosong kelapa sawit mengakibatkan perbedaan pada rasio $\mathrm{C} / \mathrm{N}$ dan peningkatan nutrisi makro ( $\mathrm{N}, \mathrm{P}$ dan $\mathrm{K}$ ) dan hara mikro ( $\mathrm{Zn}, \mathrm{Fe}, \mathrm{Cu}$ dan $\mathrm{Mn}$ ).

\section{KESIMPULAN}

Hasil analisis menunjukkan setelah proses pembuatan mol POME bahwa :

1. Hasil analisis POME menunjukkan terjadi peningkatan sifat kimia seperti fosfor dari 0,01 menjadi 0,02 , kalium dari 0,19 menjadi 0,27 , dan karbon organik dari 0,90 menjadi 1,30 , tetapi beberapa sifat kimia seperti $\mathrm{pH}$ menurun dari 7,20 menjadi 3,37 dan nitrogen menurun dari 0,37 menjadi 0,05 .

2. Hasil analisis kompos tandan kosong kelapa sawit menunjukkan bahwa $\mathrm{pH}$ tertinggi adalah p2 dengan nilai $8,23, \mathrm{C}$ organik tertinggi pada perlakuan $\mathrm{p} 4$ dengan nilai $57,65, \mathrm{~N}$ total tertinggi pada $\mathrm{p} 3$ dengan nilai $1,80, \mathrm{P}_{2} \mathrm{O}_{5}$ total tertinggi pada $\mathrm{p} 3$ dengan nilai 0,64 , dan $\mathrm{K}_{2} \mathrm{O}$ total tertinggi pada $\mathrm{p} 4$ dengan nilai 2,68.

\section{DAFTAR PUSTAKA}

Adam, S., S.S.N. Syd Ahmad., N.M. Hamzah., N.A. Darus, N.M. Hamzah, N.A. Darus, 2016. Composting of Empty Fruit Bunch Treated with Palm Oil Mill Effluent and Decanter Cake. Regional Conference on Science, Technology and Social Sciences (RCSTSS 2014). Springer Science+Business Media Singapore

Balai Penelitian Tanah. 2005. Petunjuk Teknis Analisis Kimia Tanah, Tanaman, Air, dan Pupuk. Badan Penelitian dan Pengembangan Pertanian. Departeman Pertanian. Bogor
Bernal, M. P., C. Paredes, M. A. Sanchez and J. Cegarra. 1998. Maturity and stability parameters of composts prepared with a wide range of organic wastes. Biores. Technol., 63: 91-99.

Handayani, Ahmad Y, Ari S. Uji Kualitas Pupuk Organik Cair Dari Berbagai Macam Mikroorganisme Lokal (Mol). El-Vivo Vol.3, No.1, Hal 54 - 60, April 2015 Issn: 2339-1901

Jusoh MLC, Manaf LA, Latiff PA (2013) Composting of rice straw with effective microorganisms (EM) and its influence on compost quality. Iran J Environ Health Sci Eng 10:17

Juwita, A, A. Mustafa, dan R. Tamrin. Studi Pemanfaatan Kulit Kopi Arabika (Coffee Arabica L.) Sebagai Mikro Organisme Lokal (Mol). AGROINTEK Volume 11, No. 1 Maret 2017

Kaman, S.P.D., I.A.W. Tan and L. L. P. Lim. 2017. Palm oil mill effluent treatment using coconut shell - based activated carbon: Adsorption equilibrium and isotherm. Matec Web Conf. Volume 87 : 1-6

Kastalani. 2010. Pengaruh Tingkat Konsentrasi dan Lamanya Inkubasi EM4 Terhadap Kualitas kimia Pupuk Bokashi. Media SainS, Volume 2 Nomor 2, Oktober 2010. ISSN 2085-3548. Hal 146-152

Kesumaningwati, R., Dhonanto, D dan Palupi, N. P. 2013. Aplikasi tandan kosong kelapa sawit dan mikroorganisme lokal (MOL) keong emas pada tanah bekas tambang batubara. Laporan Hibah Bersaing DIKTI. Samarinda

Kusuma, M. 2012. Pengaruh Beberapa Jenis Pupuk Kandang Terhadap Kualitas Bokashi. Jurnal Ilmu Hewani Tropika Vol 1 No. 2 Desember 2012. ISSN : 2301-7783. Hal 4146

Mercy, B.Y., Herdhata, A., Dan Dwi, A. 2013. Pengaruh Tingkat Kematangan Kompos Tandan Kosong Sawit Dan Mulsa Limbah Padat Kelapa Sawit Terhadap Produksi Tanaman Tomat (Lycopersicon Esculentum 
Mill.) Pada Tanah Ultisol. Sains Tanah Jurnal Ilmu Tanah dan Agroklimatologi 10 (2): $91-100$

Metting, F. B. 1993. Soil microbial ecology. Application of agricultural and environmental management. (Ed.) Marcel Dekker, New York.p.184.

Parnata, Ayub. S. 2004. Pupuk Organik Cair (Aplikasi dan Manfaatnya) Agromedia Pustaka. Jakarta

PPKS, 2008. Jurnaln Penelitian Kelapa Sawit. Vol 13 No. 2

Rosenani., R. Rovica., P. M. Cheah., And C. T. Lim. 2016. Growth Performance And Nutrient Uptake Of Oil Palm Seedling In Prenursery Stage As Influenced By Oil Palm Waste Compost In Growing Media. Hindawi Publishing Corporation International Journal Of Agronomy Volume 2016:1-8

Seni, Ida Ayu N. I Wayan Dana Atmaja. Ni Wayan Sri Sutari. 2013. Analisis Kualitas Larutan MOL (Mikroorganisme Lokal) Berbasis Daun Gamal (Gliricidia sepium). Ejurnal Agroekoteknologi Tropika ISSN: 2301-6515 Vol. 2, No. 2, April 2013.

Subandriyo, Didi D.A, Hadiyanto. Optimasi Pengomposan Sampah Organik Rumah Tangga Menggunakan Kombinasi Aktivator Em4 Dan Mol Terhadap Rasio C/N. Jurnal Ilmu Lingkungan. Volume 10 Issue 2: 70-75 (2012) Issn 1829-8907

Suhastyo, A, I. Anas, D. Santosa, dan Y. Lestari. Studi Mikrobiologi Dan Sifat Kimia
Mikroorganisme Lokal (Mol) Yang Digunakan Pada Budidaya Padi Metode Sri (System Of Rice Intensification). Sainteks Volume X No. 2 Oktober 2013

Supriyati, T. Pasaribu, H. Hamid, dan A. Sinurat. Fermentasi Bungkil Inti Sawit Secara Substrat Padat Dengan Menggunakan Aspergillus Niger. Solid State Fermentation Of Palm Kernel Meal By Using Aspergillus Niger. Jurnal Ilmu Ternak Dan Veteriner 3 (3): 165-170.

Tia W. P., and M. Syafila. 2018. Screening The Effect of $\mathrm{Cu}, \mathrm{Mn}$, and $\mathrm{Mg}$ on Ethanol Formation in Degradation Process of Palm Oil Mill Effluent (POME) under Anaerobic Condition Using Two-Level Factorial Design Method. Matec Web Conf.Volume $147: 1-8$

Yadnya Seni, I. A., I Wayan D. A., Ni W. S. Analisis Kualitas Larutan Mol (Mikoorganisme Lokal) Berbasis Daun Gamal (Gliricidia Sepium). E-Jurnal Agroekoteknologi Tropika ISSN: 2301-6515 Vol. 2, No. 2, April 2013

Yahya, A., Sye, C. P., Ishola, T. A., \& Suryanto, H. (2010). Effect of adding palm oil mill decanter cake slurry with regular turning operation on the composting process and quality of compost from oil palm empty fruit bunches. Bioresource Technology, 101(22), 8736-8741.

Yuwono, M. 2008. Dekomposisi dan Mineralisasi Beberapa Macam Bahan Organik. Jurnal Agronomi Vol. 12 No. 1, Januari - Juni 2008. ISSN 1410-1939. Hal 1-8 